\title{
Origin of Some Contemporary Social Habits in the Ancient Egyptian Love Poems
}

\author{
Hesham Ezz Eldin
}

University of Sadat City, Faculty of Tourism and Hotels, Guidance Department

\begin{abstract}
This paper presents the origin of some contemporary habits in the Egyptian society from the love poems of ancient Egypt. These included the custom of presenting golden jewels to the bride, the tradition of visiting sacred places and making love charms to gain the beloved and the romantic view to the girl's imagination about the heroic dream knight. The paper also displays the suggestive existence of the Cupid the angel of love in a poetic verse beside common sayings concerning the trap of love, the beauties of a girl and proverbs.
\end{abstract}

Key Words: Origin - Habits - Poems - Ancient Egypt.

\section{Introduction}

Ancient Egyptian Love Poems presented various motifs that described feelings between the lovers, the beauties of the girl, the power of love with its two contradicting sides that revived the hearts of the lovers or caused moral sickness so the lovers could not sleep at night or enjoy the life entertainments, the wishes of the lovers to be united that accompanied invocations to deities, the hidden desires to exchange love while other poems described the fantastic environment that surrounded the lovers represented in the Nile River and trees and flowers (Fox, 1985, Vernus, 1992 and Landgráfová, I, 2009). Indeed the love poems presented images about part of the romantic life in ancient Egypt that reflected the culture of the community.

The purpose of this paper is to indicate the early existence of some contemporary social habits in the ancient Egyptian love poems. These include traditions and customs as well as common sayings that are used widely in certain occasions. The paper will depend on the previous studies that presented the transcription, the transliteration and the translation of the remarkable New Kingdom love poems that included the Chester Beatty Papyrus, the Harris Papyrus 500 and the Cairo Love Songs.

\section{Cupid and the Trap of Love}

Cupid was the god of love and desire in the classical mythology (Larousse, 1995, p. 215). Until nowadays he represents the icon of love. His image as an innocent child with two wings and being equipped with a bow and arrow symbolically referred to his role in penetrating the hearts with love. It seems interesting to realize resemblance between the name of Cupid and the Egyptian entity Chester Beatty papyrus. This appeared in a man's invocation to an important person named Mehy who was suggested to be a prince (Smither, 1948, p. 116). 
The man demanded from Mehy to mention his goodness to Kpw-tpy whose name means "Chief Ensnared" (Gardiner, 1931, pl. XXIIIA; Vernus, 1992, p. 65 and note 13 in p. 174 and Landgráfová I, 2009, p. 106 and 108).

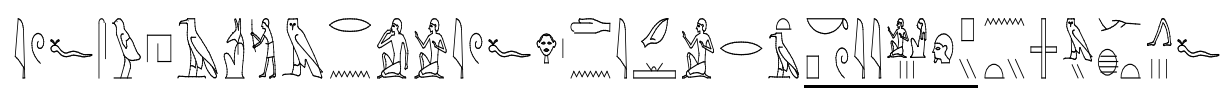

iw.f swh3 $m$ rn.i iw.f hr dni.i r t3 kpyw tpy nty imyw ht.f

"May he praise my name (and) may he is upon assigning me to the Chief Ensnared, in his followers".

The name of this Kpyw-tpy that means "Chief Ensnared" draws an image of this entity that resembles the famous image of Cupid with his arrow.

From another point the state of being captured with love, a girl's heart is said to be penetrated by the arrow of love and a man fell in the net of love. Beside a man after his marriage is said to have entered the golden cage. Amazingly the previous mentioned expressions are featured in some ancient Egyptian poetic verses.

For the penetrated heart by the arrow of love its meaning can be found in the verse from the Harris papyrus 500 that referred to the role of heaven in sending love to a man like a shooting arrow (Fox, 1985, p. 9 and 370-371 [2] (1,9), Landgráfová I, 2009, p. 118-119 and Mathieu, p. 57).

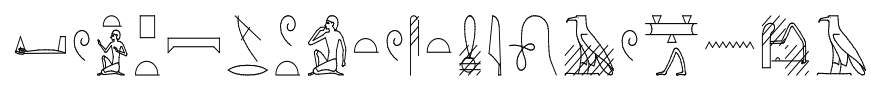

di t3 pt mrwt.s mi w3 n ‘ ḩ

"The heaven gives her love like a path of an arrow".

For the expression that refers to the fall in the net of love, the origin of this romantic concept is found in a verse that rhetorically described the hair of the girl as a trap in the Harris Papyrus (Fox, 1985, p. 9, Mathieu, 1996, pls. 8, 12 and 9, 1 and Landgráfová I, 2009, p. 172-174).

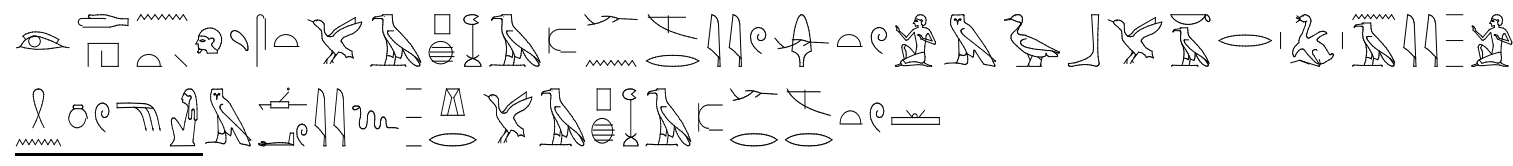

[ptr] dhnt.s p3 ph3 n mryw twi m gb krt n3y.i ....̌̌nw.t m w'wyt hr p3 ph3 mrw

" [Look] her forehead is a wooden bird trap of love (and) I am a krt goose!, my [...], the hair (is) as the worm under the wooden bird trap of love ".

In another verse from Chester Beatty Papyrus, a man expressed his fascination with the girl's hair that captured him (Fox, 1985, p. 73 and 402 [43](17,2) and Landgráfová I, 2009, p. 209):

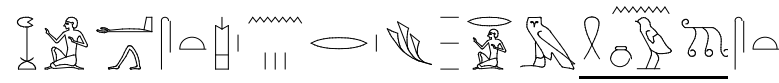

ḩ3. $s\{t\}$ iwn r\} r.i m šnw.st

"She cast a loop at me from her hair". 
Admitting the influence of the hair of the girl that attracted a man as expressed by the poet, a tradition is still witnessed especially in the countryside where the girls are used to cover their hair. A girl shows her hair to the mother of the man who proposes for the marriage as a habit to show her beauty.

Concerning the descriptive term given to a man after his marriage represented in entering the "golden cage", its origin is suggested from the Harris Papyrus among the speech of a girl who went to the marshes with snare and cage. These equipments symbolically referred to her intention to capture a man rather than birds as understood in the poem (Fox, 1985, p. 17 and 374 [9](4.2-4.3) and Landgráfová I, 2009, p. 174-175).

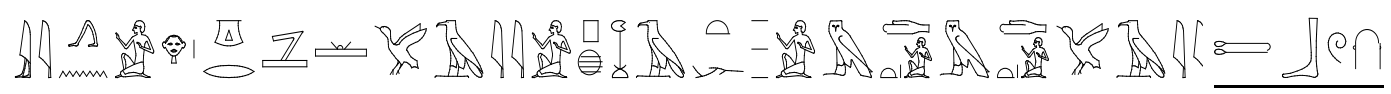

ỉ.n.i hr grg p3y.i ph3t.í m-

"I came to hunt my bird, my bird trap (is) in my hand (and) in my (other) hand (is) the bird crate ".

For the association of the cage with the golden color, this might have some sort of relation with the golden goddess Hathor who united between the lovers. This suits the name of goddess in a poetic verse represented as (Gardiner,1931, pl. XXIVA). The half of the name $H w t$ is the sign of an enclosure plan (Allen, 2010, p. 439, sign O6) while the second half $h r$ is written with the male face (Allen, 2010, p. 428, sign D2). This differs from the traditional way of writing the goddess's name represented as the enclosure place with the falcon bird inside it (Wb III, 5.11 and Allen, 2010, p. 439, sign O10). This refers to the role of women that manifested the earthly incarnation of Hathor as mentioned above in enclosing men with care and tender.

\section{Love Charms}

Love charms are made to capture the heart of the beloved one. It is essential to write the name of the mother of the intended person to guarantee the effectiveness of the charm. The origin of this belief is suggested from a poetic verse in the Chester Beatty Papyrus when a girl invoked goddess Hathor to cause the mother to allow her see the man she loved (Gardiner, 1931, pl. XXVA and Fox, 1985, p. 55).

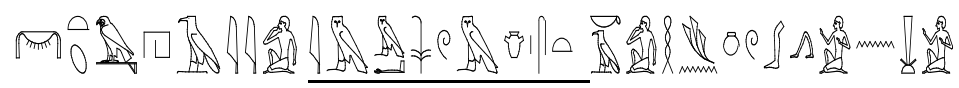

nwbt h3 imi-sw m ib.s k3 hn.i $n$ sn.i

" The Golden O, put it in her heart, so I will go speedily to my brother".

The girl's request from Hathor refers to the respectful social regard towards the important position of the mother as $n b t$ pr "lady of the house" (Erman, 1971, p. 151). This was emphasized in the teachings of Any who praised the role of the mother in taking care of her offspring and therefore she deserved to be 
esteemed (Erman, 1971, p. 155). As a result the mother was believed to possess certain influence over the emotions of her offspring. This belief can be suggested from two Middle Kingdom stelae of the person Amenemhat no. JE 45626 (fig. 1) and the one that carries no. 20697 (fig. 2) in the Egyptian Museum. It is noticed that the mother whose position is behind the son is extending her left arm to place the hand on the left arm of her son towards the side of his heart -centre of senses- as if she was supplying him with her emotions. For girls they are usually positioned as if following their mothers (Erman, 1971, p. 151). In addition the deceased mentioned that he got his heart from his mother in spell 30 from the Book of Coming Forth by the Day (Faulkner, 1989, p. 55). Accordingly it was essential to gain the satisfaction of the mother -in-law which is a well established tradition witnessed until nowadays.

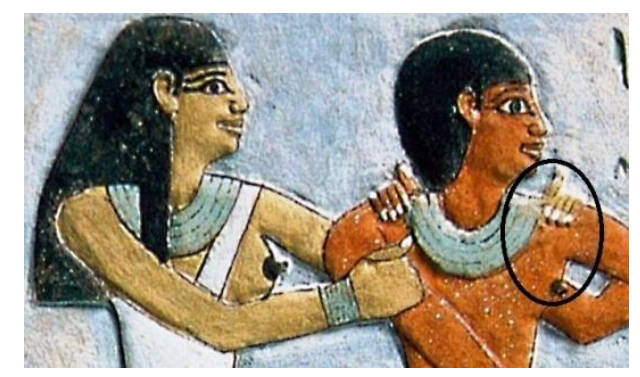

Fig. 1, after Von Zabern, 1987, no. 79.

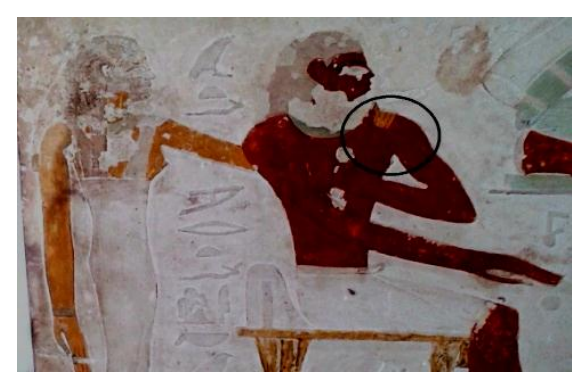

Fig. 2, after the researcher.

The mother's authority over the behavior of her offspring especially what was related to the matters of love was expressed in two poetic verses from the Chester Beatty Papyrus. Firstly she prevented her daughter from seeing the one she loves because he ignored her feelings (Gardiner, 1931, pls. XXIIA-XXIIIA and Landgráfová I, p. 103 and 104).

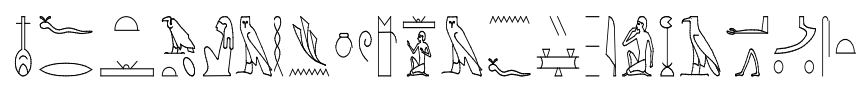

nfrt mwt.i m hnww.i m nf3 i ḩ $3^{\top} \mathrm{m} 33$-st

"My mother (is) good in commanding me thus: "abandon seeing him!".

The previous text also expressed the mother's eagerness to protect the daughter's dignity in the society. This is featured in another verse from the Chester Beatty I fourth stanza when a girl invoked her troubled heart not to expose her miserable feelings that would let people speak about the fail of her love: " do not allow people to say about me: this woman has fallen because of love " (Landgráfová I, p. 109 and 110).

Secondly a girl wished that her beloved would communicate with her mother when he knew her feelings of love towards him (Gardiner, 1931, pl. XXIIIA and Landgráfová I, p. 103 and 104-105).

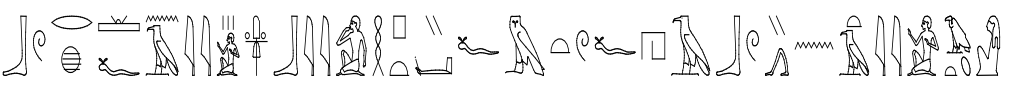

bw rh.f $n 3 y . i$ 3bw hpt.f mtw.f h3b $n$ t3y.i $m w t$ 
"He does not know my desire to embrace him (or) he would send to my mother".

The previous verse referred to the behavior of the man in sending a delegate mainly represented in his mother to propose to the girl's mother. For the mother seemed the prominent part in the fulfillment of marriage in ancient Egypt (Antelme, 2001, p. 78). This is a social tradition that can still be witnessed in modern time especially in the village community.

In addition a remarkable charm refers to the necessity of mentioning the mother's name so the man would have complete control over her daughter. As a result the daughter would find herself unable to live without the man in her life. This is clearly expressed the recitations of the person who saluted ReHorakhty, the seven Hathor and the gods of heaven and earth to make the woman born of the mother to come after him eagerly like a cow after grass, a servant following her offspring and the shepherd after his cattle or he would burn Busiris and Osiris (Smither, 1941, p. 131; Borghouts, 1978, p. 1; McDowell, 1999, p. 33 and Landgráfová I, 2009, p. 148). The cruel threat of the speaker to burn Osiris the lord of the underworld seems unreasonable but this might represent the origin of the suggestive method used by the conjurer to ascertain the belief in his dominating power to enslave the underworld genii and to hurt them if they did not fulfill his orders. This also refers to the popular propaganda for the conjurer who pretends his ability to communicate with genii and demons that have their settlement beneath earth. They are given the Arabic call "Asiad أسياد" that means "masters". According to this, the conjurer takes various kinds of payments from the customers to guarantee the fulfillment of their demands through gaining the satisfaction of these masters.

\section{Visiting Places of the Blessed Ones}

Some poetic verses refer to the origin of the tradition of visiting places of the sacred ones to order to obtain their blessings and to gain the beloved ones. This tradition is clearly mentioned in the Papyrus Harris 500 among the text of the man who went to Memphis during a festival and visited the temple of its principal god Ptah (Fox, 1985, p. 11, 12 and 372 [5](2,6) and (Landgráfová I, 2009, p. 192 and 193):

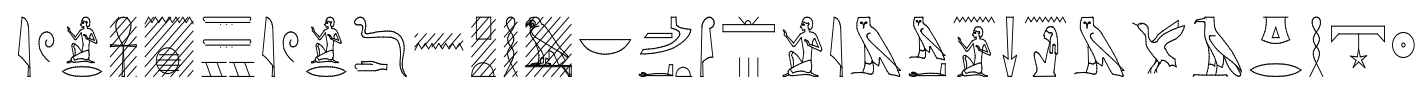

iw.i r ‘nh-t3wy iw.i $r \underline{d} d$ n Pth nb m3`t imi n.i sn(t) $m$ p’ grh.

"I am going to Ankh-Touy, I will say to Ptah, lord of Ma'at: Give me my beloved tonight".

It seems interesting to find at the end of the poem that included the previous verse the description of god Ptah as "Beautiful of Face" (Landgráfová I, 2009, p. 193 and Fox, 1985, p. 372 [5].2,9). This epithet might refer to the internal desire of the lover to have the same good visage of the god in the eyes of the girl he loved. This might have relation with the description of 
Ptah as the god who shaped mankind as mentioned in the hymns of king Usermaatre Mereamun in Papyrus Harris I (Foster, 1995, p. 109). This hypothesis depends on the name of the person Nfr-hr-n Pth "Beautiful Face of god Ptah" whose statue no. JE 87804 is exhibited in the Egyptian Museum (Erman, 1971, footnote 11 in p. 159 and Von Zabern, 1987, no. 56). This is considered one of the main required purposes in the charms of love to make a person see the other one with marvelous look. On the other hand evil spells with the purpose of separating between the two lovers worked to make them see each other with bad and horrible look.

In addition, people in modern society promise to make vows through distributing food to the poor people especially those who settle near places of the saints as sort of gratitude to the fulfillment of their needs. This tradition was expressed in some poetic love verses. From Chester Beatty Papyrus, a girl promised to make a feast for the goddess Hathor after gaining her beloved one (Landgráfová I, 2009, p. 183 and 185 and Fox, 1985, 55).

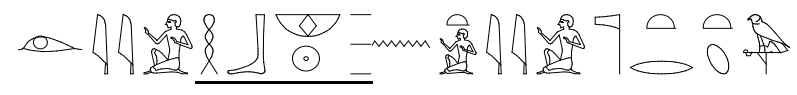

iry.i habw $n$ t3y.i ntrt

"I will make a festivals for my goddess".

In another verse from the ostraca Deir Al-Madina number oDm 1266 and oCGC 25218, B,6, a man promised to make a feast for a god if he let the one he loved came to him (Fox, 1985, p. 38 and 388 [21F](24-25) and Landgráfová I, 2009, p. 125-126).

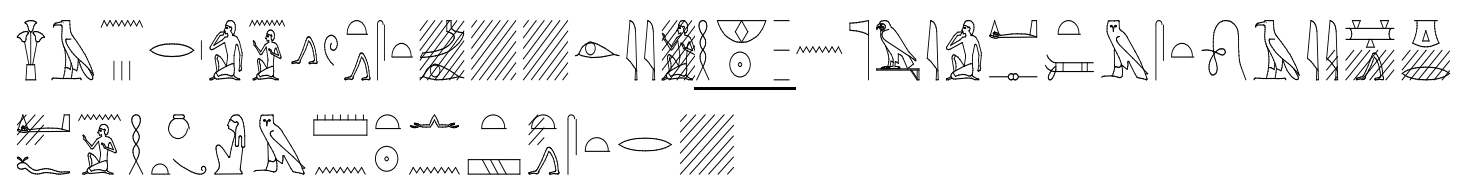

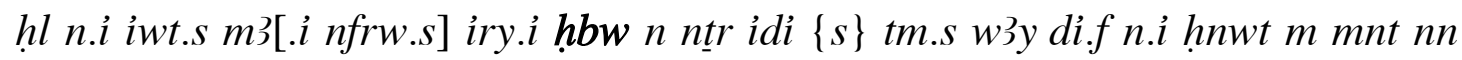
$t \check{s} t . s r[. i \quad \ldots]$.

"I wish she will come, so that I see [her beauty], I will make festivals for the god, who makes her not to be far, so that he gives me (my) mistress every day, without being far from [me]".

\section{Presenting the Golden Jewels to the Bride}

One of the principal conditions of marriage is the procedure of presenting the golden jewels known in Arabic language as "shabka" beside the dowry by the bridegroom to the bride to prove her valuable position in his heart. In ancient Egypt gold was a precious stone and it was associated with the sun god Re and his vital power (Wilkinson, 1992, p. 171 and Wilkinson, 1994, p. 83 and Pinch, 1994, p. 81).

The following poetic verses from the Chester Beatty Papyrus might lead to suggestion about the origin of this costly custom: 
(a) A man showed his gratitude to goddess Hathor because she heard his plea and gave him the beloved one (Gardiner, 1931, pl. XXIVA; Fox, 1985, p. 54 and Landgráfová I, 2009, p. 112-113).

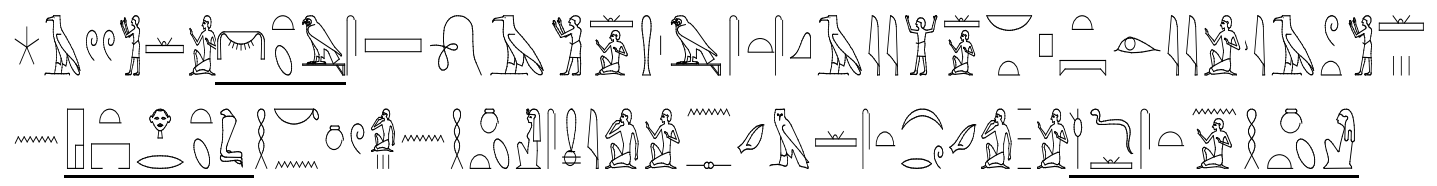

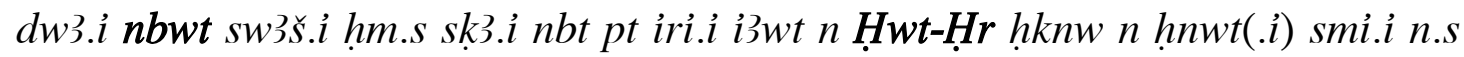
sdm.s sprw.i wd.st n.i hnwwt.i

"I praise the Golden One, I honor Her Majesty, I make high the Mistress of Heaven. I make adoration to Hathor (and) acclaim to my Mistress. I appeal to her and she hears my petitions. She commands to me my mistress ".

(b) Although a girl morally suffered because the one she loved did not show any positive sign towards her feelings but she seemed optimistic because of the interference of goddess Hathor (Gardiner, 1931, p. 31 and pl. XXIIIA; Fox, 1985, p. 53; Vernus, 1992, p. 65 and Landgráfová I, 2009, p. 103 and 105).

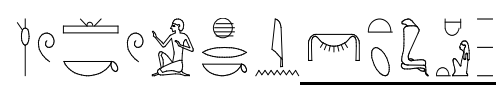

\section{wd.kwi hr.k in nbwt ḥmwt}

"I am decreed to you by the Golden One of Women ".

(c) A man is determined to gain his beloved because of the help of goddess Hathor (Fox, 1985, p. 117-118 and 400, g.25).

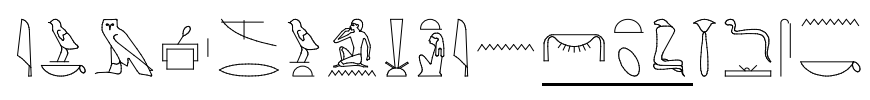

iw. $k m$ s3 mrwt $n$ snt in $n b w t w d-s t ~ n . k$

"You are after the love of your sister by the Golden One who decrees her for you".

(d) A man invoked goddess Hathor to give him the beloved one as a divine donation (Gardiner, 1931, pl. XXIVA, Fox, 1985, p. 54 and Landgráfová I, 2009, p. 112 and 114).

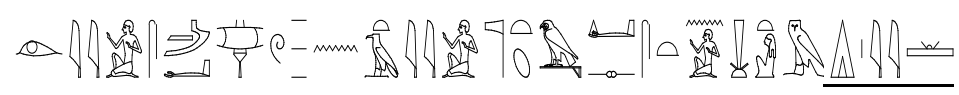

iri.i sm3` $n$ t’3y.i ntrt di.s n.ỉ snt(.i) $m$ diw

"I prayed to my goddess, that she would give me my beloved as a gift".

(e) In another verse from Chester Beatty Papyrus goddess Hathor gave a man the girl as a gift to have eternal happy life with her (Iverson, 1979, p. 80-81 and note 5 in p. 81-82; Fox, 1985, p. 71 and 401-402, (17.1) and Landgráfová I, 2009, p. 165-166).

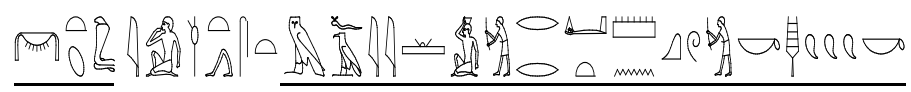

$n b w t$ iwd-st $m f 3 y(t) r$ rdit mnqw.k ${ }^{\top}{ }^{\top} w . k$ 
" The Golden One O, send her as a reward in order to make you complete your lifetime $"$.

From the previous poetic verses the divine role of Hathor is obvious in uniting the lovers together. The goddess was given the epithet of Golden One " (Leitz, 2002, p. 180-182). This is considered normal for she was the daughter of the sun god Re whose solar disk surmounted her head (Wilkinson, 2003, p. 140 and 143 and Landgráfová I, 2009, p. 113). Being described as the "rint this might refer to considering girls as the earthly incarnation of goddess Hathor. This concept is also suggested when a girl offered her breast to nourish her lover in a verse: (Landgráfová I, p. 159-160 and Fox, 1985, p. 8). For the manner of this girl is considered an imitation to the well known divine role of Hathor in giving her breast to feed the kings with her sacred milk (Roberts, 2000, p. 22 and Wilkinson, 2003, p. 141). The association of Hathor with women was also incarnated through her title "Lady of the Vulva" (Antelme, 2001, p. 34 and Wilkinson, 2003, p. 141).

Verses (d) and (e) considered girls as divine $\Delta$ H "reward" respectively from Hathor to provide men with pleasure. This might refer to the necessity of presenting golden jewel in return to the girls as sort of showing gratitude to goddess Hathor. This is expressed in a verse from the Chester Beatty Papyrus when a man invoked goddess Hathor to give him the beloved one as a divine donation (Gardiner, 1931, pl. XXIVA; Fox, 1985, p. 54 and Landgráfová I, 2009, p. 112 and 114). Enjoying pleasure with the girl naturally as a spouse to the ending moment of life, as expressed in verse (e) might refer to the symbolic role of the jewels especially the rings that took the shape of shen sign of eternity (Wilkinson, 1992, p. 193 and Shaw, 2002, p. 267-268). In the Middle Kingdom the shen rings were used as protective amulets (Shaw, 2002, p. 267). The shen sign was associated with goddess Hathor who is shown while holding it in her famous group statue with king Menkaure from the Fourth Dynasty in the Egyptian Museum (Von Zabern, 1987, no. 33). Accordingly golden jewels especially the rings symbolized the wish of the man to have eternal life with the beloved one which was encircled with the blessing and the protection of Hathor. This was expressed in a verse from the Cairo Love Songs through the promise of girl to devote her life with the husband (Fox, 1985, p. 31 and 383 [20A](6) and Landgráfová, I, 2009, p. 145 and 146).

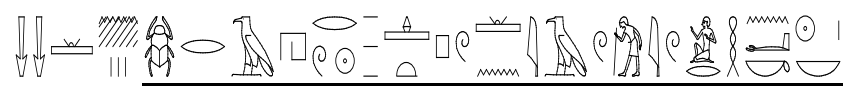

\section{[...] snsn.n hpr hrw htpw n i3wt iw.i hn ${ }^{\complement} . k r^{\top}-n b$}

" $[\ldots]$ we will be together [...], until the day of resting in old age comes, I will be with you everyday". 
As a result among the contemporary congratulating expressions to the married couple is to enjoy an eternal life full of happiness.

\section{The Dream Knight}

A romantic view is usually associated with the teenaged girl represented in imagining the coming of the lover while riding white horse to take her with him. This heroic image is expressed in many stories and songs with the term "Dream Knight". Some ancient Egyptian poetic verses might have indication for the origin of the dream night.

From Chester Beatty Papyrus, a girl wished that her lover would be like a royal messenger in order to reach her quickly (Gardiner, 1931, pl. XXIXA and Landgráfová I, 2009, p. 114).

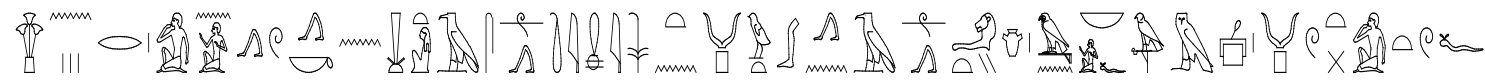

hl n.i ilw.k n snt 3sty mi wpwt-nsw n 3s ḩ3ty n nb.f m-s3 wpwt.f

"Wish you come to (your) beloved quickly like a royal messenger because of the hurry heart of his lord, following after his message".

The main keen of the messenger to reach the house of the beloved was expressed in a successive verse from the same poem (Gardiner, 1931, pl. XXIXA and see Landgráfová I, 2009, p. 115).

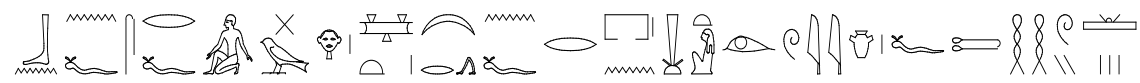

bn n.f srf ḥr w3t spr.n.f r pr n snt iri ib.f tḥhwt

"there is no rest for him on the road, and when he reached the house of (his) beloved, his heart will rejoice".

In another verse from Chester Beatty Papyrus, a girl desired to be united with the beloved who was in a distant place and she rhetorically wished him to be like a royal horse in order to reach her quickly (Gardiner, 1931, pl. XXIXA; Landgráfová I, 2009, p. 115-117; Fox, 1985, p. 66 and Lichtheim, II, 2006, p. 186-187).

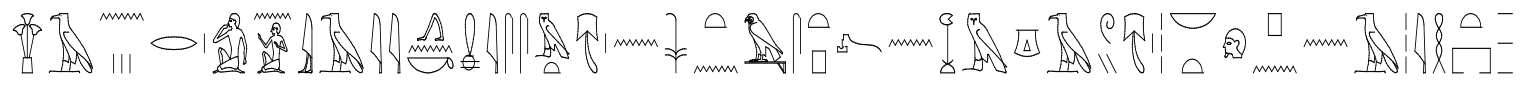

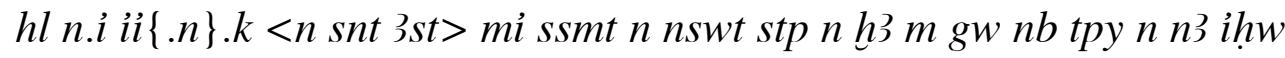

"Wish you would come quickly to your beloved, like a horse of the king, the choicest of a thousand of stallions, the first of the stables".

Identifying the lover with the horse is also found in another verse from the Harris Papyrus 500. A girl who was suffering from the inability of enjoying her life, due to the absence of her lover, wished that he would come quickly to her like a horse in the battlefield (Fox, 1985, p. 8-9 and 370 (1.8) and Landgráfová I, 2009, p. 118-119).

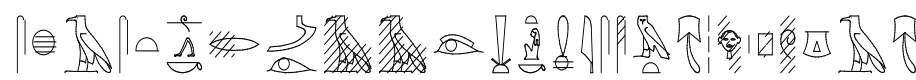

sh3h.k r m33 snt.k mi ssmt hr pg3 
"May you hasten to see your sister, like a horse (dashing) [onto a battle]field".

The military aspect in the last poetic verse is considered a normal reflection to the glorification period of the New Kingdom that witnessed numerous military victories. Without any doubt the feelings of the Egyptians were filled with pride. This was incarnated through the battle scenes of the triumphant king who was accompanied by his troops that included charioteers who in turn possessed high rank in the society. As a result a girl started to draw the perfect image of her lover as a heroic charioteer as an internal desire to live safely under his protection.

On the other hand a charioteer expressed desire to see his beloved girl in Ostraka of Deir el-Madina number oDM 1078 Ro (Fox, 1985, p, 79 and Landgráfová I, 2009 p. 138).

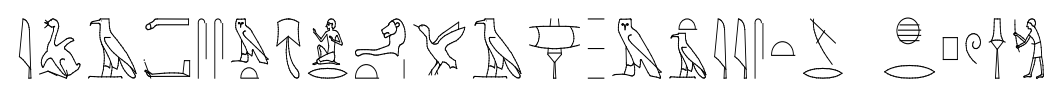

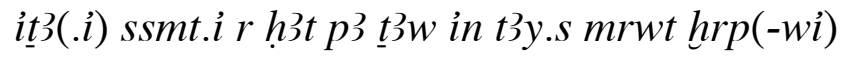

"I will take my horse, faster than the wind, it is her love that drives me!".

Amazingly the last verse inspired the usage of such modern popular expressions when a person says that he would come on the wing of speed or he would make a race with the wind.

\section{Beauty of the Girl.}

According to Haikal, identifying a beautiful woman with the moon in the contemporary praising expression is originally inspired from a verse in the Chester Beatty Papyrus that described an exquisite woman as a morning star (Haikal, 1999, p. 80 and Landgráfová I, and H. Navrátilová, 2009, p. 92 and 94). In addition there are welcoming expressions that are still in use like nawart el-makan and el-ard minawara bi wgwdak that means "you brightened the place" and "the land is brightened by your existence" respectively were found in a poetic verse when telling a beautiful girl that she made the land more bright (Haikal, 1991, p. 80-81).

Among the flattering sentences said to the gorgeous attractive girl is " there is no one who enjoys your beauty". This expression almost resembles the description of a beautiful one by a man who could not hide his admiration. The unbearable beauties of a girl were remarkably expressed in the poems written in the Cheater Beatty Papyrus (Gardiner, 1931, p. 30 and pl. XXIIA; Fox, 1985, p. 52; Vernus, 1992, p. 63 and Landgráfová I, 2009, p. 92 and 93-94).

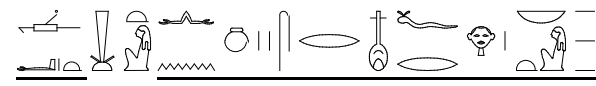

\section{$w^{\top} t \operatorname{snt}(. i) n n$ sn-nw.s (r) $n f r t<r>h r n b w(t)$}

"Unique is (my) beloved, with no second, more beautiful than anyone".

For the beautiful one who attracts the attention of men, a common expression used is "she turned their necks towards her". This is found in a following 
verse from last stanza that praised the girl who looked like a sparkling star in the extreme beautiful details of her face and body. This is early expressed in a following position from the previous stanza (Gardiner, Chester Beatty, p. 30 and pl. XXIIA and Landgráfová I, 2009, p. 93 or 97).

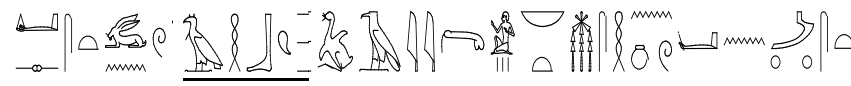

di.s wn nḥbw ţ’yw nb msnḥw $n$ m33.st ršwt ḥpt st

"she makes the necks of all men turn in order to look at her".

From the previous verse the existence of the male sexual organ in the word $\underline{t} 3 y w$ "men" after $n h b w$ " necks" might refer to the hidden desire of the men to be united with the beautiful one. This is emphasized in a following verse

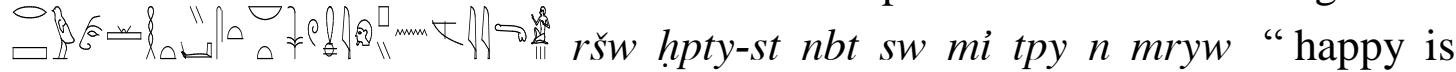
everyone who embraces her, being like the first of lovers" (Gardiner, 1931, pl. XXIIA and Landgráfová I, 2009, p. 97).

\section{A Ring in a Finger}

There is a popular description concerning a man who usually accomplishes the requests of his wife as " a ring in her finger". This shows to what extent he is under the control of his wife. It seems amazing to suggest the origin of this ironic expression in a verse. A lover, in order to be so close to his beloved, wished to be a ring in her finger (Fox, 1980, p. 103; Fox, 1985, Egyptian Love Songs, p. 38 and 387 (21D) and Landgráfová, Golden Goddess I, p. 121-122).

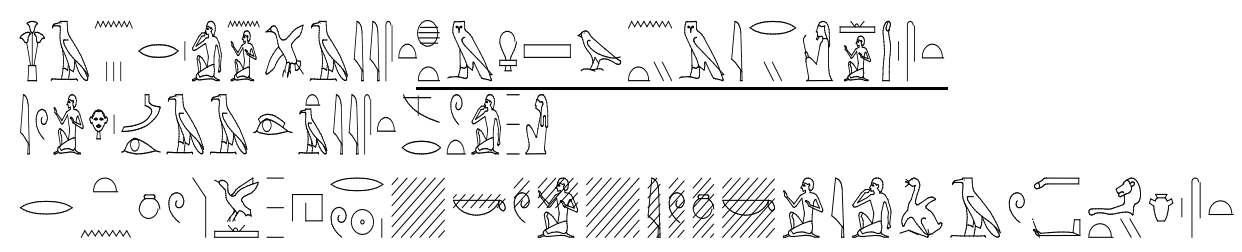

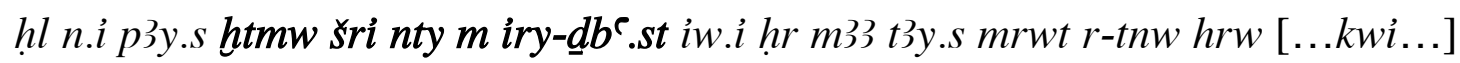
[iw ink] it 3 w hl 3 ty.s.

"I wish I were her little signet ring which is in her finger, I would see her love every day, and it would be I who would touch her heart everyday while it would be I who would seize her heart".

\section{A Man's Stomach !}

A widely used famous proverb concerning the intention of a girl to capture the heart of a man is "the way to gain the heart of a man is through his stomach" (Michael, 2012, p. 15). This idiom is considered a precious advice for a girl to know recipes for preparing delicious food to gain the satisfaction of her man. It seems interesting to find the origin of this saying concerning the man's appetite towards food in a verse from the papyrus Harris 500. A girl blamed a man because he did not respond to the seduction of her beauty and moreover she realized with her female cleverness his desire to leave her. So she enquired if he wanted to leave because of the obligation to satisfy his hungry stomach 
(Fox, 1985, p. 8 and 370 [1] (1.3); Landgráfová I, 2009, p. 159-160 and Mathieu, 1996, p. 56).

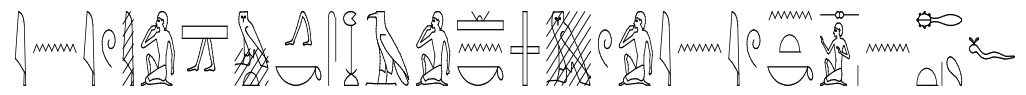

in iw išm.k sḩ3 n.k wnm in iw ntk s $n$ h ht.f

"Is it because of having thought of food that you are leaving?, are you a man of his belly?".

The previous verse refers to another popular belief that the beauty of the girl is not enough for she must possess the required advantages to provide her husband with comfortable life. This concept is found in another poem from the Cairo Love Songs through the speech of the girl who devoted herself to satisfy her man (Fox, 1985, p. 31 and 383 [20B] (6) and Landgráfová, I, 2009, p. 146).

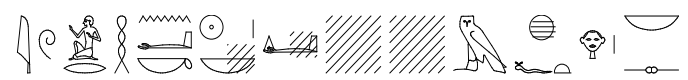

iw.i $r$ - hhn $n^{\top} . k r^{\top}-n b$ di [//II] $m$ hft-hrr nb.s

"I will be together with you every day setting [food] in the front her master".

\section{The "Entry Night" Expression}

The wedding ceremony is associated with the common expression "night of entry" for it witnessed the first intercourse between the married couple. There might be indications of the origin of this widely used expression through the word gate, gateway and double door in various poetic verses. They were suggested to symbolize the girl's vagina in some poetic verses (Fox, 1985, p. 14 and 70 and Landgráfová, I, 2009, p. 163-164). For instance a verse from the Chester Beatty Papyrus described the desire of the man to be united with his beloved one by reaching her rwty " gateway (Fox, 1985, p. 14 and p. 400 [40] $(\mathrm{g}, 2,4)$ and Landgráfová I, 2009, p. 117-118).

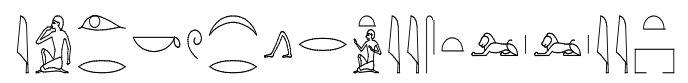

i ir.k spr r t3y.s rwty

"O, you will reach her gateway".

\section{Cutting a Fish and its Tail !}

A usual expression given to a lusty man who captures the admiration of women is "he is cutting a fish and its tail". Although this sentence seems understandable but it bears a hidden meaning that refers to the sexual potency of this man in ancient Egypt (Antelme, 2001, p. 81). The origin of this concept can be found in a remarkable poetic verse from the Cairo Love Songs. It associated a girl who was bathing in the river and the fish with erotic indication. (Fox, 1980, p. 103, Fox, 1985, p. 32 and 384[20C](10), Kitchen, 1999, p. 383, Antelme, 2001, p. 81 and Landgráfová I, 2009, p. 178 and 179180).

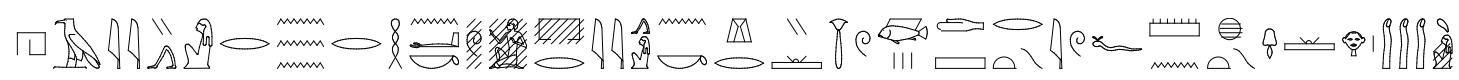




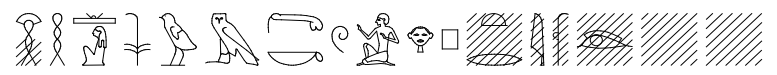

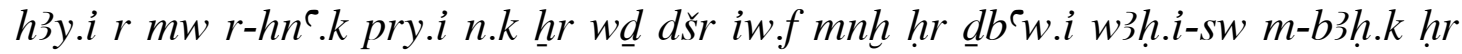
$p[\ldots]$

"I will go down to the water together with you, I will come out to you carrying a red fish which is in my fingers. I will set it before you while lo[oking upon your beauty]".

There is a suggestion that the red fish was rhetoric significance for the heart of the girl who presented it to her lover (Landgráfová, I, 2009, p. 179 and Mathieu, 1996, p. 171-179). So the expression "cutting the fish and its tail" refers to the ability of the man in capturing the hearts of the women. Identifying the heart with the fish which was in turn described to be red in the preceding of the last poem might be the origin of associating the heart with the red color. From another point of view the fish $w \underline{d}$, Nile Bass, Tilapia nilotica was believed to symbolize potency (Fox, 1985, p. 34-37). The erotic indication of fish and its association with love at night also features in another verse from the Cairo Love Songs. A man while expressing his happiness because of the coming of the girl to spend the night with him identified his heart with a fish (Fox, 1985, p. 32-33 and 385 [20E](14) and Landgráfová, I, 2009, p. 136).

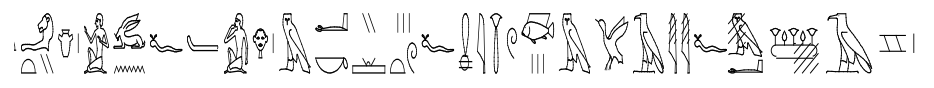

h3ty.i wnf hr mkt.f mi wd $m$ p $3 y . f m \check{s}$

" my heart is happy in its place as fish in its pond".

\section{Conclusion}

There are numerous indications that consider the ancient Egyptian love poems as essential sources for knowing the origin of numerous social cultural habits and traditions in the modern society of Egypt.

For the popular sayings, it is noticed the different concepts of some expressions in the love poems and the contemporary used proverbs. A wish for a man to be a ring in the finger of his beloved intended to show his great and faithful love. But nowadays it is understood with a negative indication for reflecting the weakness of a man before his wife. On the other hand, the famous proverb advising a girl to gain the heart of a man through his stomach was originally used as blame from the woman to the man because of his desire to leave her in order to eat.

The origin of Cupid the angel of love can be proved to be a development from the name of the Egyptian entity Kpyw tpw who was responsible for sending the arrow to penetrate the hearts with love. Also in the common taking the expression of falling in the net of love and entering the golden cage are initially found in the ancient love poems. In addition sentence with hidden erotic meaning of using fish with its symbolic potency are still in use. In addition the rhetoric identification of the gate with the woman's vagina seemed to be the origin of using the term "night of entry" after the wedding of the beloved couple. 
The poems also presented the standards of the beautiful woman who was identified with star and she attracted the attention of men whose necks turned to her, which are commonly used in expressions.

There is evidence that associated the golden rings presented to the brides with the ancient role of Hathor the goddess of love, represented in encircling the lovers with her eternal blessing. The roots of the popular practices concerning the regular visits to the sacred places and the love charms that included the name of the beloved's mother were referred in some poetic verses.

At the end it can be concluded that the Egyptian love poems represent valuable source for the cultural heritage of the Egyptians.

\section{References}

Allen J.P., Middle Egyptian. An Introduction to the Language and Culture of Hieroglyphs, Cambridge University Press, 2010.

Antelme R.S. and Rossini S., Sacred Sexuality in Ancient Egypt. The Erotic Secrets of the Forbidden Papyrus, translated by Graham J., Inner Traditions. Rochester, Vermont, 2001.

Borghouts J.F., Ancient Egyptian Magical Texts, E.J.Brill, Leiden, 1978.

Erman A., Life in Ancient Egypt, Dover Publications Inc, New York, 1971.

Faulkner R.O., The Ancient Egyptian Book of the Dead, The British Museum Press, London, 1989.

Foster J.L., Hymns, Prayers and Songs. An Anthology of Ancient Egyptian Lyric Poetry, Scholars Press, Atlanta, Gorgia, 1995.

Fox M.V., "The Cairo Love Songs", in JAOS 100, 1989, p. 101- 109.

Fox M.V., The Song of the Songs and the Ancient Egyptian Love Songs, the University of Wisconsin Press, Madison - London, 1985.

Gardiner A.H., The Library of A. Chester Beatty: Description of a Hieratic Papyrus with a Mythological Story, Love-Songs and other Miscellaneous Texts.

The Chester Beatty Papyri No. 1, the Oxford University Press, London, 1931.

Griffiths J.G., "Love as a Disease", in Israelit-Groll (ed.), Studies in Egyptology. Presented to Miriam Lichtheim I, The Magnes Press, The Hebrew University, Jerusalem, 1990, p. 349-364.

Haikal F., "Thoughts and Reflexions on the Love Songs in Ancient Egypt" in L'Impero Ramesside, Rome 1999, p. 77-85.

Iverson E., "The Chester Beatty Papyrus, No. I, Recto XVI, 9-XVII, 13” in JEA 65, 1979, p. 78-88.

Landgráfová R. and Navrátilová H., Sex and the Golden Goddess I. Ancient Egyptian Love Songs in Context, Prague, 2009.

Lichtheim M., Ancient Egyptian Literature. Volume II: The New Kingdom, University of California Press, 2006.

Leitz Chr., Lexikon der Ägyptischen Götter und Götterbezeichmungen. Band IV: nbt-h, OLA 113, Leuven-Paris-Dudley, MA, 2002.

Mathieu B., La Poésie Amoureuse de L'Egypte Ancienne. Recherches sur un genre littéraire au Nouvel Empire, BdE 115, IFAO, Le Caire, 1996. 
McDowell A.G., Village Life in Ancient Egypt. Laundry Lists and Love Songs, Oxford University Press, 1999.

Michael N., Fall in Love Again. Secret to Unlock your Man's Heart and Win Him Back, 2012, p. 15.

Pinch G., Magic in Ancient Egypt, British Museum Press, 1994.

Roberts A., My Heart My Mother. Death and Rebirth in Ancient Egypt, Northgate Publishers, England, 2000

Shaw I. and Nickolson P., The British Museum Dictionary of Ancient Egypt, The American University in Cairo Press, 2002, p. 267-268.

Smither P. C., " A Ramessside Love Charm " in JEA 27, 1941, p. 131-132.

Smither P.C., "Brief Communications: Prince Mehy of the Love Songs", in JEA 34, 1948, p. 116.

Taylor J.H., Death and the Afterlife in Ancient Egypt, The British Museum Press, 2001.

Vernus P., Chants d'Amour de l'Egypte Antique, Paris, 1992.

Von Zabern P., Official Catalogue. The Egyptian Museum Cairo, Mainz. Germany, 1987.

Wilkinson R.H., Reading Egyptian Art: A Hieroglyphic Guide to Ancient Egyptian Painting and Sculpture, Thames \& Hudson, New York, 1992.

Wilkinson R.H., Symbols and Magic in Egyptian Art, Thames and Hudson, London, 1994.

Wilkinson R.H., The Complete Gods and Goddesses of Ancient Egypt, Thames and Hudson, London, 2003.

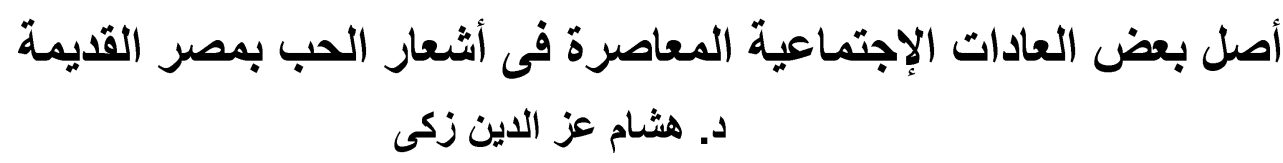
ملخص البحث عربى

يهدف البحث إلى رصد أصل بعض العادات الإجتماعية المعاصرة من أثنعار الحب فى مصر القداريمة

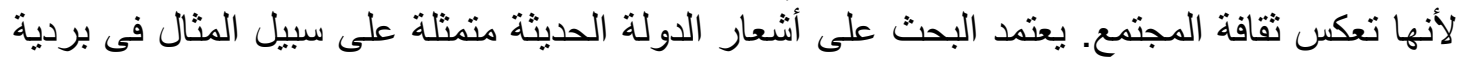

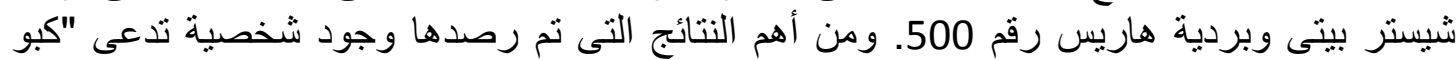

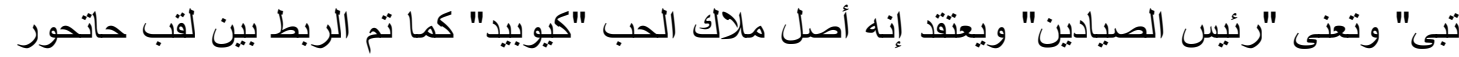

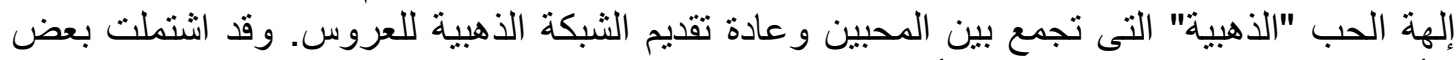

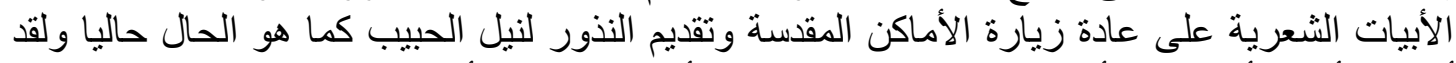

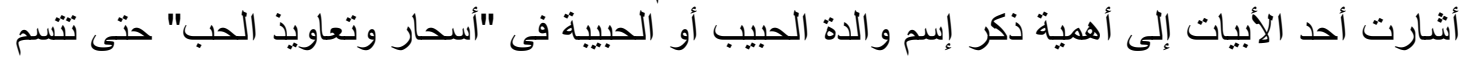

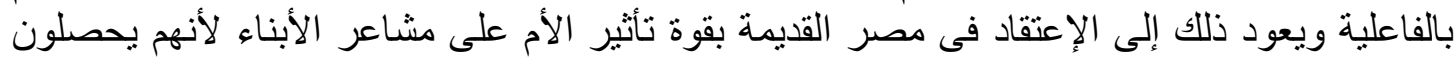
على قلوبهم منها.

كما تم عرض أبيات شعرية التى تعد المصدر الذى أدى إلى استخدام بعض التعبيرات المعاصرة التى التى

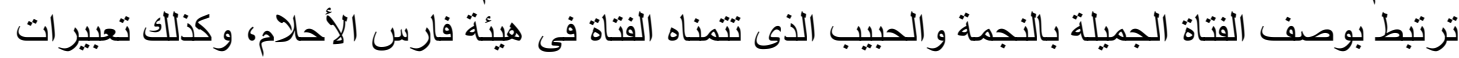
أخرى تجرى على الألسنة مثل التى تصف الرجل بإنه مثل الخاتم فى إصبع زوجنه فارسه أو كنصيحة مثل

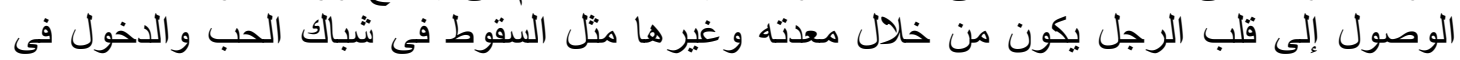

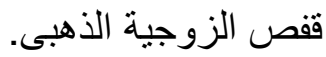

